\title{
Urban growth and transport: understanding the spatial temporal relationship
}

\author{
M. Aljoufie ${ }^{1,2}$, M. Zuidgeest ${ }^{1}$, M. Brussel ${ }^{1} \&$ M. van Maarseveen ${ }^{1}$ \\ ${ }^{I}$ Department of Urban and Regional Planning and Geo-information \\ Management, ITC Faculty of Geo-Information Science and \\ Earth Observation, University of Twente, The Netherlands \\ ${ }^{2}$ Department of Urban and Regional Planning, Faculty of \\ Environmental Design, King Abdul Aziz University, Saudi Arabia
}

\begin{abstract}
Transport and urban growth are strongly related. In fact, there is a reciprocal relationship between transport and urban growth. To understand this relationship, it is necessary to analyze urban spatial temporal changes and their related causes and effects. In this paper, an extensive evidence-based and scientific description of the relationship between urban growth and transport is presented. This relationship is specifically explored for Jeddah city, Saudi Arabia, applying spatial temporal analysis techniques from remote sensing and Geographic Information Systems. Spatial and statistical analyses have been used to analyze and relate urban growth and transport spatial temporal indicators. Results indicate a strong reciprocal relationship between urban growth and transport in Jeddah city. It is found that transport infrastructure expansion strongly correlates with population growth, spatial expansion and land use change. Results also reveal that population growth has increased urban trips and the consequent travel demand, and there is imbalance between travel demand and transport infrastructure supply which explains the increase in congestion. This study also points out a strong significant influence of transport infrastructure on spatial temporal expansion and land use change. It is found that highways and main roads have stronger influence on spatial expansion and land use change in comparison with secondary roads. Although, this study provides significant information for transport and urban development policies, further research is
\end{abstract}


encouraged to use spatial statistical analysis and dynamic modelling to study the reciprocal relationship between urban growth and transport.

Keywords: urban growth, transport, spatial temporal analysis, indicators, remote sensing, GIS, Jeddah city.

\section{Introduction}

In 2004 , over $48 \%$ of the world's population estimated in urban areas, and by 2030 this figure is predicted to increase to $61 \%$ United Nations [1]. Accordingly, urban areas will continually witness a rapid urban growth that will impose further challenges to urban planners. Urban growth is not emerges phenomena that can be observed directly in urban areas. In fact, variety of factors trigger urban growth: transport and communication, [2-4]; internal and international migration, [5]; public policies, $[6,7]$ and globalization of economic activities [810]. Understanding urban growth, its drivers and the future impact on the urban environment is of prime concern to urban planners Al-Ahmadi et al. [11].

Transport plays a vital role in urban development. Transport systems provide essential mobility options for people and goods and influences patterns of growth and the level of economic activity through the accessibility it provides to land (Meyer and Miller [12]). Urban growth and transport are strongly related issues. On the one hand, transport infrastructure attracts urban development, on the other hand, urban growth and population cause an increase in travel demand and thereby an increase in the requirement for transport infrastructure. Previous studies have focused mainly on the causes and effects of transport and urban growth.

In general, there is a lack of research on the mutual relationship between urban growth and transport, while less attention has been paid to the spatial temporal aspects of this relationship. Understanding the transport and urban dynamics increasingly becomes a necessary condition for developing urban development strategies [13-18]. To provide a better understanding of this relationship, this paper analyzes this for the case of Jeddah city, Saudi Arabia. Initially, this paper provides an extensive evidence-based and scientific description of the relationship between urban growth and transport. Thereafter, it strives to relate and analyze the relationship between urban growth and transport through spatial temporal indicators using statistical and spatial analyses. These spatial temporal indicators of urban growth and transport have been developed and quantified using remote sensing and GIS techniques.

\section{Literature review}

Urban areas are in their nature dynamic, complex structures and are pertinent to the growth in different terms physical, economic and population which so called urban growth. Urban growth is a complex process that involves spatial temporal changes of urban areas socio-economic and physical components Han et al. [15]. These changes are catalyzed by many drivers and underlying factors. Among these, transport is considered one of the main factors of urban growth. Advances 
in the transport system have reduced the cost of commuting within urban areas and encouraged urban scattering, [19, 20]. Equally, transport infrastructure expansion has stimulated urban growth and land use changes, [2-4, 16].

At the same time, urban growth affects transport. Urban growth patterns configure urban spatial structure and thus influence transport. Urban growth not only increases travel demand, [21-23] but also, causes infrastructure pressure and consequently traffic congestion, [16, 24, 25]. Therefore, urban growth is strongly related to transport with reciprocal causes and effects. Causality, reciprocal effects, and reciprocal causes are apparent characteristics of urban growth and transport relationship. However, the relationship could be inferred at four main interacted aspects: transport infrastructure, travel demands, population and land use change, fig. 1.

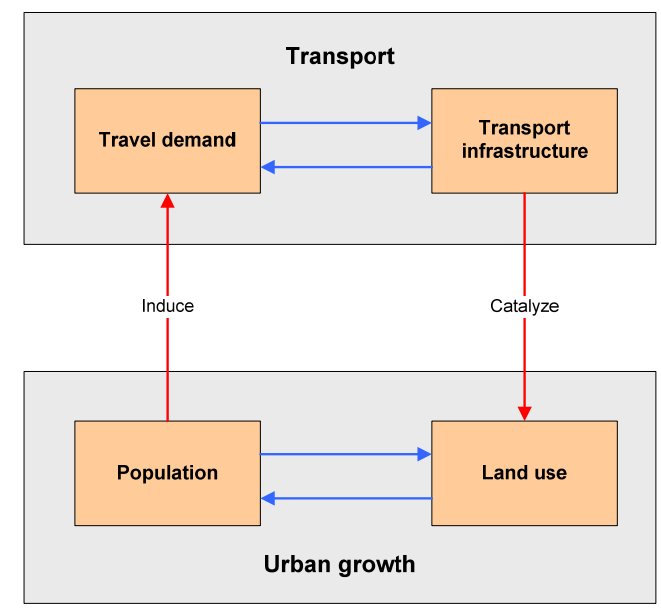

Figure 1: Conceptual reciprocal relationship of urban growth and transport.

In general, previous studies have focused only on the aspects of causes and effects of transport and urban growth relationship. However, spatial temporal processes of this relationship have not been addressed before. To address this, quantification of the spatial temporal situation of urban growth and transport has to be carried out. Integration of remote sensing (RS) and geographic information system (GIS) techniques and the establishment of appropriate indicators provide the capacity to quantify this intrinsic relationship between urban growth and transport.

\section{Methodology}

\subsection{Study area}

Jeddah is the second largest city in the Kingdom of Saudi Arabia with a population exceeding three million. Jeddah is located on the West coast of the Kingdom at the confluence of latitude 29.21 North and longitude 39.7 East, in 
the middle of the eastern shore of the Red Sea and surrounded by the plains of the Tahoma in the east, fig. 2.

The city of Jeddah has witnessed a dramatic increase in population, due to out-migration from villages and suburbs to the city in search of jobs and a better living. The strength of the economy and growth in population are increasingly straining the city's transport system. Jeddah is car dominated with residents using private automobiles for $93 \%$ of trips IBI [26]. The challenges of accelerated urban expansion, population growth and traffic congestion are predominant issues in Jeddah city today. The local government of Jeddah city, its transport planning department in particular, faces challenges in managing, and planning of the transport system in view of the urban expansion.

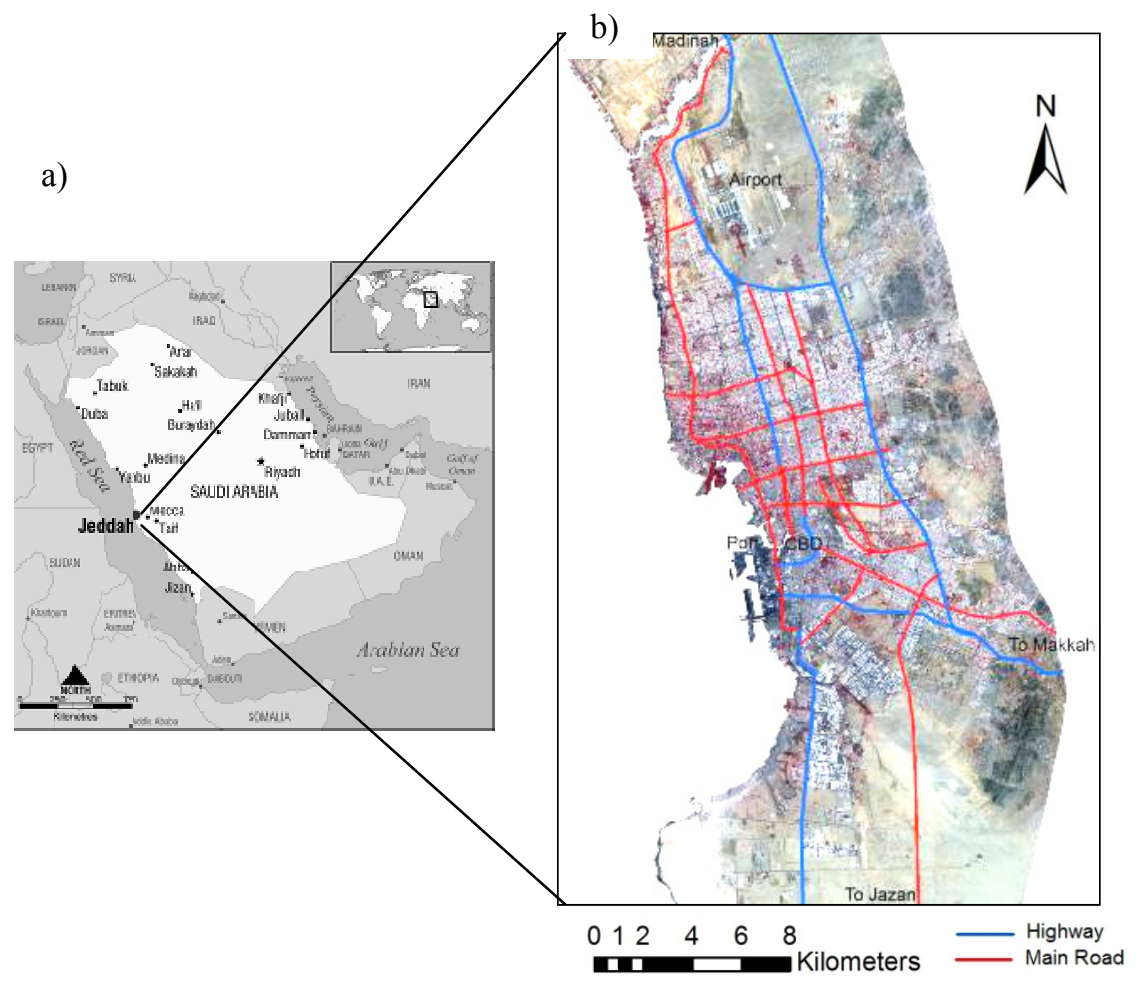

Figure 2: a) Geographic location of Jeddah (source: en.wikipedia.org/wiki /Jeddah) b) Jeddah city.

\subsection{Data and image processing}

This study utilizes a time series of Aerial photos and Satellite images for quantifying the spatial-temporal urban growth and transport system situation from 1964 to 2007. Aerial photos data of 1964, 1970 and 1980 have been used for the period before 1981. After that period, Spot Satellite images data of 1993, 
2004 and 2007 have been used. Moreover, a variety of secondary data were collected to facilitate spatial temporal analysis of urban growth and transport in Jeddah city. These data include: Jeddah Master plans for year 1963, 1973, 1980, 1987, and 2004; Jeddah Transport Studies for year 1980, 1995, 2004 and 2007; Census data 1993 and 2005, Urban Growth Boundaries Study 1986 and Jeddah topographic maps 2000 .

Firstly, image-to-image registration strategy has been adopted for georeferencing the various images using polynomial model second order function in ERDAS IMAGINE. Subsequently, a cooperative visual interpretation method is applied to quantify temporal urban land use and transport infrastructure as the main aspects of urban growth and transport in Jeddah city. The process started with unsupervised image classification to differentiate between urban built-up elements and none built-up elements using the ISODATA clustering algorithm in ERDAS IMAGINE. This process shows the spatial pattern of urban built up area in Jeddah city which facilitates a better acquaintance of the elements of built up area such as buildings, roads infrastructure and green areas. Next, land use and transport infrastructure reference data, from master plans and transport studies reports, were integrated with built up and none built images using overlay function in ArcGIS. Ten urban land use classes were specified to be extracted: residential, commercial, industrial, institutional, informal settlements, airport, port, roads, vacant lands and green areas. Thereafter, visual interpretation indicators such as pattern, shape, and size were extensively used in identifying features from aerial photographs and satellite imageries based on the field knowledge. Consequently, cooperative visual interpretation has been conducted incorporating all aforementioned process in ArcGIS v9.3 using on-screen digitizing, overlay tools and area of interest (AOI) functionality. Accordingly, land use and transport infrastructure maps of 1964, 1972, 1983, 1993 and 2007 have been obtained. Finally, accuracy assessments were performed based on a comparison of the cooperative interpretation outputs with the reference data. The average overall accuracy of land use maps produced by this approach was $90,5 \%$.

\subsection{Statistical analysis}

To examine the spatial temporal relationship between urban growth and transport, indicators represent the effective tool. Seven indicators have been developed to quantify the spatial temporal urban growth and transport situation as follows:

\subsubsection{Annual urban spatial expansion index}

$$
\text { AUSEI }=\frac{\left(U_{i}-U_{j}\right) /\left(U_{i} \times 100\right)}{N_{i-j}}
$$

where AUSEI is the annual urban spatial expansion index; $U_{i}$ and $U_{j}$ are the total urban areas of the study area in hectare at time $i$ (former year) and time ${ }_{j}$ (latter year); $N_{i-j}$ is the total number of years from time $i$ (former year) to time ${ }_{j}$ (latter year). 


\subsubsection{Land use change index}

$$
L U C I=\frac{L U_{a i}-L U_{a j}}{L U_{a j}} \times 100
$$

where $L U C I$ is the land use change index; $L U_{a i}$ and $L U_{a j}$ are the total land area of land use class a in hectare at time $i$ (former year) and time ${ }_{j}$ (latter year).

\subsubsection{Population density index}

$$
P D I=\frac{\sum P_{i}}{\sum U_{i}}
$$

where $P D I$ is the population density index; $\sum P_{i}$ is the total population at time $i$ and $\sum U_{i}$ is the total urban land in hectare at time $i$.

\subsubsection{Transport infrastructure expansion index}

$$
T I E I=\frac{\sum T I L_{i}-\sum T I L_{j}}{\sum T I L_{i}} \times 100
$$

where TIEI is the transport infrastructure expansion index; $\sum T I L_{i}$ and $\sum T I L_{j}$ are the total transport infrastructure length of road class a in kilometres at time $i$ (former year) and time ${ }_{j}$ (latter year).

\subsubsection{Road density index (area, per capita)}

$$
\begin{gathered}
R D I_{-} A=\frac{\sum R L_{i}}{\sum U A_{i}} \\
R D I_{-} C A P=\frac{\sum R L_{i}}{\sum U P_{i}}
\end{gathered}
$$

where $R D I$ is the road density index; $\sum R L_{i}$ is the total road lengths in kilometres at time $i ; \sum U A_{i}$ is the total urban areas area in hectare at time $i ; \sum U P_{i}$ is the total urban population in the study area at time $i$.

\subsubsection{Road area density index (area, per capita, residential)}

$$
\begin{gathered}
R A D I_{-} A=\frac{\sum R A_{i}}{\sum U A_{i}} \times 100 \\
R A D I_{-} C A P=\frac{\sum R A_{i}}{\sum U P_{i}} \\
R A D I_{-} R E S=\frac{\sum R A_{i}}{\sum U R A_{i}}
\end{gathered}
$$

where $R A D I$ is the road area density index; $\sum R A_{i}$ is the total road areas in hectare at time $i ; \sum U A_{i}$ is the total urban areas area in hectare at time $i ; \sum U P_{i}$ is the total urban population in the study area at time; $\sum U R A_{i}$ is the total urban residential area in hectare at time $i$.

\subsubsection{Urban trips density index (per capita, residential)}

$$
\begin{gathered}
\text { TDI_CAP }=\frac{\sum U T_{i}}{\Sigma U P_{i}} \\
\text { UTDI_RES }=\frac{\sum U T_{i}}{\Sigma U A R_{i}}
\end{gathered}
$$


where $U T D I$ is urban trip density index; $\sum U T_{i}$ is the total number of urban trips at time $i ; \sum U P_{i}$ is the total urban population in the study area at time $i ; \sum U A R_{i}$ is the total urban residential area in square meter at time $i$.

Statistical analysis of the quantified indicators has been performed using SPSS 18 software. Pearson correlation analysis has been implemented to determine the reciprocal relationship between urban growth and transport indicators. The followings relationships have been examined:

- Relationship between transport infrastructure expansion index and various urban growth indices (population growth - spatial expansionland use change).

- Relationship between road density index and spatial expansion.

- Relationship between road area density index and urban trip density index.

- Relationship between urban trip density index and population growth.

\subsection{Spatial proximity analysis}

To derive the influence of transport infrastructure in spatial temporal urban growth, spatial proximity analysis has been considered. Buffer analysis function of GIS has been used to analyze the effects of transport infrastructure in the spatial temporal urban growth of Jeddah city from 1964 to 2007. The process, depicted in figure 3 , starts with extracting the temporal changes of spatial

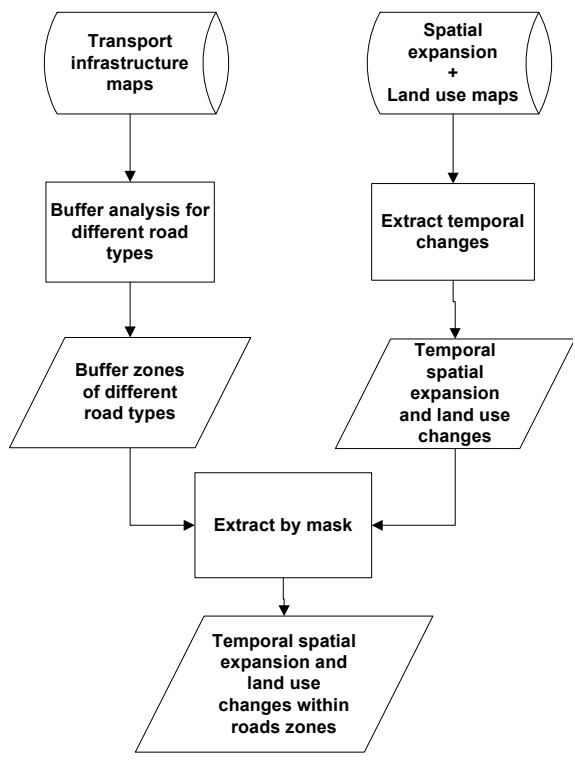

Figure 3: $\quad$ Spatial proximity analysis process. 
expansion and land use at five periods: 1964-1970, 1970-1980, 1980-1993, 1993-2002 and 2002-2007. Conversely, buffer analysis of highways, main roads and secondary roads has been performed for the respective periods. Different buffer zones have been chronologically created as follows:

1. $400 \mathrm{~m}$ (highways and main roads) and $100 \mathrm{~m}$ (secondary roads).

2. $800 \mathrm{~m}$ (highways and main roads) and $200 \mathrm{~m}$ (secondary roads).

3. $\quad 1500 \mathrm{~m}$ (highways and main roads) and $300 \mathrm{~m}$ (secondary roads).

4. $2000 \mathrm{~m}$ (highways and main roads) and $400 \mathrm{~m}$ (secondary roads).

5. $3000 \mathrm{~m}$ (highways and main roads) and $500 \mathrm{~m}$ (secondary roads).

Subsequently, temporal changes of spatial expansion and land use have masked by the created roads buffer zones. Accordingly, the percentage of spatial expansion and land use change within different roads buffer zones can be quantified.

\section{Results and discussion}

During the period 1964-2007, Jeddah city witnessed a rapid population growth, spatial expansion, land use change and transport infrastructure expansion with rates of changes ranging from 0 per cent to over 100 per cent, indicating a wide variability across space, as depicted in figure 4 and table 1. Two types of urban growth can be distinguished in Jeddah: outward expansion and sprawl development.

Table 1: $\quad$ Spatial temporal changes.

\begin{tabular}{ccccccc}
\hline Year & 1964 & 1970 & 1980 & 1993 & 2002 & 2007 \\
\hline Spatial expansion (ha) & 18315 & 18840 & 32500 & 40739 & 49700 & 54175 \\
Population growth & 149,000 & 381,000 & 960,000 & $2,046,000$ & $2,560,000$ & $3,247,134$ \\
$\begin{array}{c}\text { Transport infrastructure } \\
\text { expansion (km) }\end{array}$ & 101 & 136 & 435 & 562 & 711 & 826 \\
$\begin{array}{c}\text { Transport infrastructure } \\
\text { area expansion (ha) }\end{array}$ & 510 & 680 & 2175 & 2560 & 3375 & 3950 \\
$\quad$ Urban trips increase & - & 293,370 & 798,430 & - & $5,863,475$ & $6,051,883$ \\
Residential growth(ha) & 1945 & 2018 & 8724 & 14921 & 19318 & 21365 \\
Commercial growth (ha) & 298 & 302 & 569 & 891 & 1355 & 1555 \\
$\begin{array}{c}\text { Industrial growth(ha) } \\
\text { Public places growth }\end{array}$ & 26 & 30 & 1759 & 3793 & 6058 & 6976 \\
$\begin{array}{c}\text { Informal settlements } \\
\text { growth(ha) }\end{array}$ & 211 & 224 & 2137 & 2766 & 3351 & 4508 \\
\hline *- no data & & & & & & \\
\hline
\end{tabular}




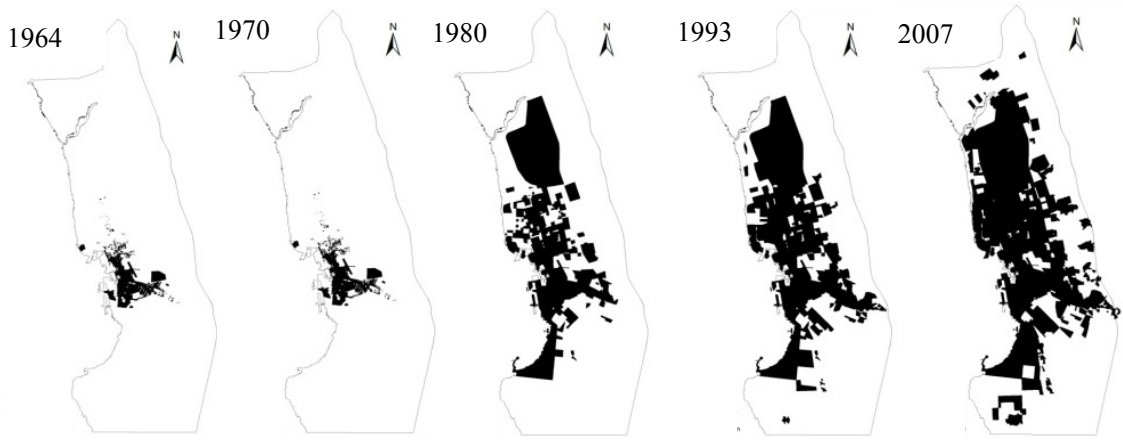

Urban spatial expansion

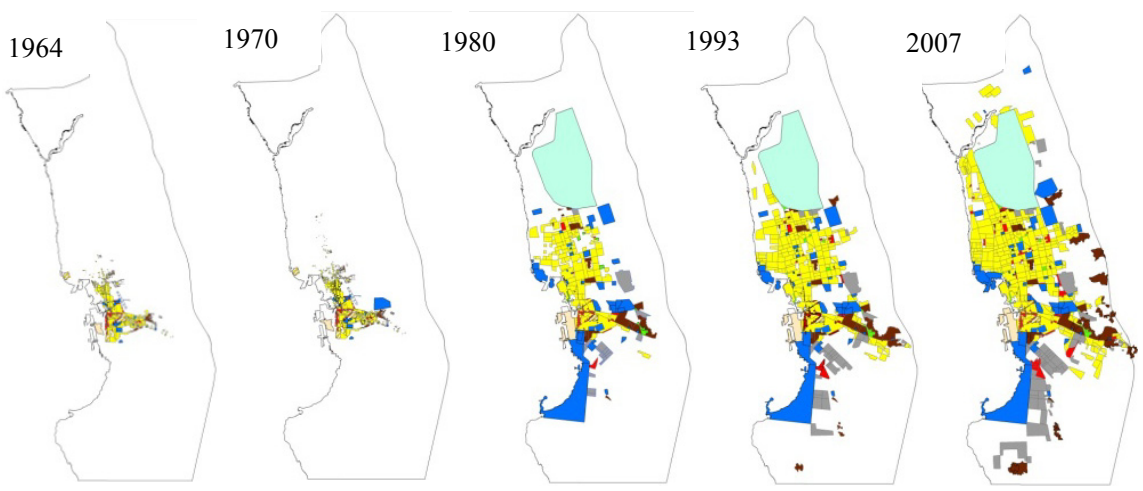

Land use change
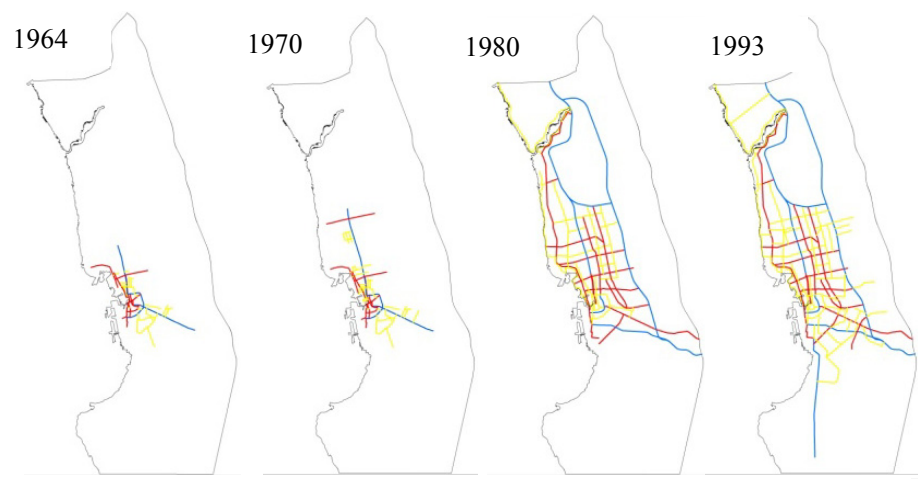

2007

Transnort infrastructure exnansion

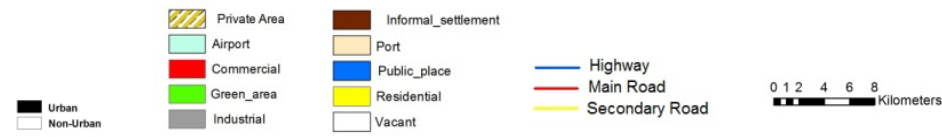

Figure 4: Jeddah spatial temporal changes. 


\subsection{Statistical analysis}

Results indicate a strong relationship between urban growth and transport. This has been revealed by the significant positive correlation between transport infrastructure expansion and urban growth indicators, see table 2 . It is found that transport infrastructure and population growth have a significant positive correlation of 0.984 . Similar significant positive correlation is found between transport infrastructure and spatial expansion $(\mathrm{r}=0.997)$ and land uses, table 2 , implying that transport infrastructure expansion has promoted the various urban spatial expansion and land use change.

Table 2: Correlation between transport infrastructure and different urban growth indicators.

\begin{tabular}{ccc}
\hline Urban growth indicators & Transport infrastructure expansion \\
\hline Spatial expansion & Pearson Correlation & $0.997^{* *}$ \\
& Sig. (2-tailed) & 0.000 \\
Population growth & Pearson Correlation & $0.984^{* *}$ \\
& Sig. (2-tailed) & 0.000 \\
Residential & Pearson Correlation & $0.992^{* *}$ \\
& Sig. (2-tailed) & 0.000 \\
Commercial & Pearson Correlation & $0.970^{* *}$ \\
& Sig. (2-tailed) & 0.001 \\
Industrial & Pearson Correlation & $0.979^{* *}$ \\
& Sig. (2-tailed) & 0.001 \\
Public places & Pearson Correlation & $0.935^{* *}$ \\
& Sig. (2-tailed) & 0.006 \\
Informal settlements & Pearson Correlation & $0.995^{* *}$ \\
& Sig. (2-tailed) & 0.000 \\
\hline
\end{tabular}

**. Correlation is significant at the 0.01 level (2-tailed).

Moreover, there is a significant positive correlation $(r=0.907)$ between the road area density index (RADI_A equation7) and spatial expansion in Jeddah city. The total area devoted to transport infrastructure notably increased from 510 ha $(2.8 \%$ of the total urban areas) in 1964 to 3950 ha $(7.3 \%$ of the total urban areas) in 2007, wherein spatial expansion increased dramatically from 18,315 ha in 1964 to 54,175 ha in 2007 , see table 1, representing an increase of $296 \%$. This indicates that spatial expansion of Jeddah has been triggered by road density area increase. On the other hand, the increase in road area density coincided with spatial expansion. Hence, there is a reciprocal relationship between spatial expansion and road area density increase.

Correlation analysis also point out a significant positive relationship $(\mathrm{r}=0.972)$ between population growth and the number of urban trips in Jeddah city. This designates the strong relationship between population growth and travel demand. Furthermore, there is a significant negative correlation $(r=-0.951)$ between road density index (RDI equation 6) and urban trips density index (UTDI equation 11). Similarly significant negative correlation is found between the road area 
density index (RADI equation 8) and urban trips density index (UTDI equation 11) $(r=-0.972)$. This reflects the gap between the rapid increase of urban trips (as a result of population growth) and the expansion of transport infrastructure, table3, which reveals an imbalance between travel demand and transport infrastructure supply and the consequent increase in congestion. In fact, congestion is now a common occurrence on Jeddah's streets and the duration of congestion is lengthening, IBI [26].

\subsection{Spatial proximity analysis}

Results also point out the significant influence of transport infrastructure on the spatial temporal expansion and land use change. Table 4 shows that during the period of 1964-2007 about 5-84\% of the total spatial expansion occurred in

Table 3: Urban trips density (UTDI), road density (RDI) and road area density (RADI) indicators.

\begin{tabular}{cccc}
\hline Year & UTDI (trip/m2) & RDI (km/person) & RADI (ha/person) \\
\hline 1964 & - & 0.00068 & 0.0034 \\
1970 & 0.015 & 0.00035 & 0.0018 \\
1980 & 0.009 & 0.00047 & 0.0023 \\
1993 & - & 0.00027 & 0.0013 \\
2002 & 0.030 & 0.00027 & 0.0013 \\
2007 & 0.028 & 0.00025 & 0.0012 \\
\hline
\end{tabular}

*- no data

Table 4: $\quad$ Spatial expansion percentages in different roads buffer zones.

\begin{tabular}{|c|c|c|c|c|c|c|}
\hline & Buffer & $\begin{array}{c}1964-1970 \\
\%\end{array}$ & $\begin{array}{c}1970-1980 \\
\%\end{array}$ & $\begin{array}{c}1980-1993 \\
\%\end{array}$ & $\begin{array}{c}1993-2002 \\
\%\end{array}$ & $\begin{array}{c}2002-2007 \\
\%\end{array}$ \\
\hline \multirow[b]{3}{*}{1} & 400 m_Highways & 6 & 9 & 16 & 10 & 12 \\
\hline & 400 m_Main Roads & 7 & 24 & 24 & 17 & 5 \\
\hline & 100 m_Secondary Roads & 5 & 6 & 8 & 12 & 12 \\
\hline \multirow{3}{*}{2} & 800 m_Highways & 12 & 19 & 29 & 20 & 23 \\
\hline & 800 m_Main Roads & 9 & 25 & 39 & 30 & 11 \\
\hline & 200 m_Secondary Roads & 7 & 12 & 17 & 23 & 25 \\
\hline \multirow{3}{*}{3} & 1500 m_Highways & 12 & 36 & 50 & 39 & 37 \\
\hline & 1500 m_Main Roads & 9 & 60 & 59 & 41 & 18 \\
\hline & 300 m_Secondary Roads & 7 & 17 & 25 & 32 & 37 \\
\hline \multirow{3}{*}{4} & 2000 m_Highways & 20 & 46 & 64 & 52 & 44 \\
\hline & 2000 m_Main Roads & 16 & 65 & 68 & 44 & 20 \\
\hline & 400 m_Secondary Roads & 77 & 23 & 33 & 40 & 48 \\
\hline \multirow{3}{*}{5} & 3000 m_Highways & 28 & 64 & 84 & 72 & 58 \\
\hline & 3000 m_Main Roads & 18 & 70 & 78 & 47 & 30 \\
\hline & 500 m_Secondary Roads & 78 & 27 & 40 & 47 & 57 \\
\hline
\end{tabular}


transport infrastructure and spatial expansion. It is found that highways and main roads have stronger influence on Jeddah spatial expansion in compare with secondary roads in the different periods. It is noticed that the effect of roads increased with the increase of buffer size. For instance, during the period 1980 to 1993, the percentage of spatial expansion occurred in the $400 \mathrm{~m}$ buffer zone of highways was $16 \%$, wherein $84 \%$ occurred in the $3000 \mathrm{~m}$ buffer zone of highways. The highest effect of all roads types on the spatial expansion is found in the period 1980-1993 wherein 8-84\% of spatial expansion occurred on different roads buffer zones. However in this period most of Jeddah roads have been constructed [table 1, 27, 28].

Spatial proximity analysis also indicates significant relationship between transport infrastructure and residential area expansion. Table 5 shows that around $7-100 \%$ of residential area expansion occurred in different roads buffer zones, which designate that transport infrastructure strongly triggered residential area expansion. It is noticed that highways and main roads have stronger influence on Jeddah residential area expansion. This is also reflected by the sprawl development of residential area in Jeddah city [27, 28].

Table 5: Residential area expansion percentages in different roads buffer zones.

\begin{tabular}{|c|c|c|c|c|c|c|}
\hline & Buffer & 1964-1970 & $1970-1980$ & $1980-1993$ & 1993-2002 & 2002-2007 \\
\hline & & & & & & \\
\hline & 400 m Highways & 32 & 8 & 17 & 12 & 18 \\
\hline 1 & 400 m_Main Roads & 35 & 38 & 30 & 24 & 7 \\
\hline & $\begin{array}{l}100 \mathrm{~m} \_ \text {Secondary } \\
\text { Roads }\end{array}$ & 31 & 12 & 12 & 15 & 17 \\
\hline & 800 m_Highways & 69 & 19 & 33 & 25 & 36 \\
\hline & 800 m_Main Roads & 35 & 67 & 49 & 45 & 14 \\
\hline 2 & $\begin{array}{l}200 \mathrm{~m} \_ \text {Secondary } \\
\text { Roads }\end{array}$ & 42 & 23 & 23 & 30 & 34 \\
\hline & 1500 m_Highways & 69 & 43 & 56 & 43 & 60 \\
\hline & 1500 m_Main Roads & 35 & 90 & 72 & 64 & 25 \\
\hline 3 & $\begin{array}{l}300 \mathrm{~m} \_ \text {Secondary } \\
\text { Roads }\end{array}$ & 42 & 33 & 33 & 43 & 50 \\
\hline & 2000 m_Highways & 96 & 57 & 67 & 58 & 70 \\
\hline 4 & 2000 m_Main Roads & 77 & 95 & 82 & 68 & 30 \\
\hline & $\begin{array}{l}400 \mathrm{~m} \_ \text {Secondary } \\
\text { Roads }\end{array}$ & 66 & 43 & 44 & 54 & 63 \\
\hline & 3000 m_Highways & 100 & 79 & 86 & 73 & 82 \\
\hline & 3000 m_Main Roads & 87 & 99 & 94 & 72 & 45 \\
\hline 5 & $\begin{array}{l}500 \mathrm{~m} \_ \text {_Secondary } \\
\text { Roads }\end{array}$ & 69 & 51 & 53 & 63 & 74 \\
\hline
\end{tabular}




\section{Conclusion}

Results indicate a strong reciprocal relationship between urban growth and transport in Jeddah city. It is found that transport infrastructure expansion strongly correlates with population growth, spatial expansion and land use change. On the contrary, urban spatial expansion and residential area growth are catalyzed by transport infrastructure expansion. It is noted that population growth have increased urban trips and the consequent travel demand. Moreover, results reveal imbalance between travel demand and transport infrastructure supply, which reflects the consequent increase in congestion.

This study also points out a strong significant influence of transport infrastructure on the spatial temporal expansion and land use change. It is found that highways and main roads have stronger influence on spatial expansion and land use change in comparison with secondary roads.

Although statistical and spatial analyses demonstrated significant information on the spatial temporal relationship between urban growth and transport, it provides limited explanation of the reciprocal relationship between urban growth and transport. Therefore, further research is encouraged to use spatial statistical analysis and dynamic modelling to study the reciprocal relationship between urban growth and transport.

\section{References}

[1] United Nations, World Urbanization Prospects: The 2003 Revision, UN: New York, 2004.

[2] Castells, M., The informational city: Information technology, economic restructuring and the urban-regional process, Blackwell Publishers: Oxford, 1989.

[3] Hall, P. \& Pfeiffer, U., Urban Future 21: A Global Agenda for TwentyFirst Century Cities, Spon: London, 2000.

[4] Hart, T, Handbook of urban studies, Sage Publications: London, 2001.

[5] Thorns, D. C., The transformation of cities: Urban theory and urban life, Palgrave Macmillan: New York, 2002.

[6] Carruthers, J., The impacts of state growth management programmes: A comparative analysis, Urban Studies, 39(11), pp. 1959-1982, 2002.

[7] Nelson, A. C. \& Duncan, J. B., Growth management principles and practices, American Planning Association: Chicago, 1995.

[8] Choe, S.C., Toward reform of Korea's green belt policy: issues and adjustment. Paper presented at the International Seminar on Management of Green Belt Area, Seoul, October ,1998.

[9] Douglass, M., (eds) New Regional Development Paradigms, Vol. 1, pp. 3356. Westport, CT: Greenwood, 2001.

[10] Marcotullio, P. J. , Globalization, urban form and environmental conditions in Asia-Pacific cities, Urban Studies, 40(2), pp 219-247, 2003. 
[11] Al-Ahmadi, K., See, L. M., Heppenstall, A. J. \& Hogg, J., Calibration of a fuzzy cellular automata model of urban dynamics in Saudi Arabia, Ecological Complexity, 6(2), pp 80-101, 2009.

[12] Meyer, M.D. \& Miller, E.J., Urban Transportation Planning: 2nd Ed, McGraw Hill: New York, 2001.

[13] Priemus, H., Nijkamp, P., \& Banister, D., Mobility and spatial dynamics: an uneasy relationship. Journal of Transport Geography, 9(3), 167-171, 2001.

[14] Cheng, J., Modelling spatial and temporal urban growth, ITC Dissertation, 99, ITC: Enschede, 2003.

[15] Han, J., Y. Hayashi, \& Imura, H. Application of an integrated system dynamics and cellular automata model for urban growth assessment: A case study of Shanghai, China, Landscape and Urban Planning 91(3): pp133141, 2009.

[16] Bhatta, B., Analysis of Urban Growth and Sprawl from Remote Sensing Data, Springer-Verlag: Heidelberg, 2010.

[17] Bhatta, B., S. Saraswati, \& Bandyopadhyay, D., Quantifying the degree-offreedom, degree-of-sprawl, and degree-of-goodness of urban growth from remote sensing data, Applied Geography, 30(1), pp 96-11, 2010.

[18] Müller, K., C. Steinmeier, \& Meinrad, K., Urban growth along motorways in Switzerland, Landscape and Urban Planning, 98(1), pp 3-12, 2010.

[19] Johnson, J. H., Urban geography: an introductory analysis, Pergamon Press: Oxford, 1967.

[20] Jackson, K., Crabgrass Frontier: The Suburbanization of the United States, Oxford University Press: Oxford, 1985.

[21] Cervero, R., Road Expansion, Urban Growth, and Induced Travel: A Path Analysis. Journal of the American Planning Association, 69(2), pp. 145163, 2003.

[22] Cameron, T.J., Lyons, \& Kenworthy J.R., Trends of vehicle kilometers of travel in world cities, 1960-1990: underlying drivers and policy responses, Transport Policy, 11 (3), p. 287, 2004.

[23] Millot, M., Urban growth, travel practices and evolution of road safety. Journal of Transport Geography, 12(3): pp. 207-218, 2004.

[24] Brueckner, J., Urban sprawl: Diagnosis and remedies. International Regional Science Review, 23(2), pp.160-171, 2000.

[25] Allen, J., Lu, K., Modeling and prediction of future urban growth in the Charleston region of South Carolina: a GIS-based integrated approach. Conservation Ecology, 8(2): 2, 2003.

[26] IBI, Group, Jeddah Public Transport Study, Ministry of Transport, Saudi Arabia, 2007.

[27] Al-Hathloul, S. \& M. A. Mughal, Jeddah, Cities, 8(4): pp. 267-273, 1991.

[28] Daghistani, A., A case study in planning implementation, University of Newcastle upon Tyne, Working paper no. 32, 1993. 